Article

\title{
Exploring Characteristics of Sustainability Stimulus Patterns of Project Managers
}

\author{
José Magano ${ }^{1,2, * \mathbb{C}}$, Gilbert Silvius ${ }^{3,4}{ }^{(0)}$, Cláudia Sousa Silva ${ }^{5}$ and Ângela Leite ${ }^{6}$ \\ 1 Research Center in Business and Economics (CICEE), Universidade Autónoma de Lisboa, \\ Rua Sta. Marta 47, $5^{\circ}$ Andar, 1150-293 Lisboa, Portugal \\ 2 ISCET-Higher Institute of Business Sciences and Tourism (ISCET), Rua de Cedofeita, 285, \\ 4050-180 Porto, Portugal \\ 3 Research Group Project Management, LOI University of Applied Sciences, Leidsedreef 2, \\ 2352 BA Leiderdorp, The Netherlands; mail@gilbertsilvius.nl \\ 4 Department of Applied Information Systems, College of Business and Economics, \\ University of Johannesburg, Johannesburg 2006, South Africa \\ 5 Departamento de Economia, Gestão, Engenharia Industrial e Turismo, GOVCOPP, Campus Universitário \\ de Santiago, University of Aveiro, 3810-193 Aveiro, Portugal; claudia.margarida@ua.pt \\ 6 School of Human and Social Sciences (ECHS), University of Trás-os-Montes and Alto Douro (UTAD), \\ Quinta de Prados, 5001-801 Vila Real, Portugal; angelal@utad.pt \\ * Correspondence: jmagano@iscet.pt
}

Citation: Magano, J.; Silvius, G.; Silva, C.S.; Leite, Â. Exploring Characteristics of Sustainability Stimulus Patterns of Project Managers. Sustainability 2021, 13, 4019. https://doi.org/10.3390/ su13074019

Academic Editor: Mark

Anthony Camilleri

Received: 9 March 2021

Accepted: 1 April 2021

Published: 4 April 2021

Publisher's Note: MDPI stays neutral with regard to jurisdictional claims in published maps and institutional affiliations.

Copyright: (c) 2021 by the authors. Licensee MDPI, Basel, Switzerland. This article is an open access article distributed under the terms and conditions of the Creative Commons Attribution (CC BY) license (https:/ / creativecommons.org/licenses/by/ $4.0 /)$.

\begin{abstract}
The role of projects in the transition of organisations towards sustainability is addressed in a growing number of studies, and "sustainable" project management is considered one of the most important project management trends today. As sustainability is a normative concept based on subjective values and beliefs, project managers are bound to experience different stimuli and inhibitors for the consideration of sustainability in their projects. Earlier studies identified three distinct stimulus patterns: Intrinsically motivated, Task-driven, and Pragmatic. However, little is known about these three groups of project managers' personal and professional characteristics and their work environments. Following up on earlier studies, this paper explores the social-demographic and professional-related characteristics that the three stimulus patterns represent in a quantitative, survey-based study on a sample of 433 project managers. Analyses of descriptive statistics (means, frequencies, and Cronbach's alpha) and inferential statistics (chi-squared, $t$ test, and ANOVA) were used. The findings of the study support the conclusion that sustainability is a personal trait based upon the individual's attitude towards sustainability. The study also reveals that the stimulus patterns of project managers significantly differ over industries and types of projects. The study intends to help organisations implement sustainability strategies by deepening their understanding of project managers' stimulus to consider sustainability in their projects. The study contributes to the emerging knowledge on sustainable project management and specifically to the understanding of stimulus patterns of project managers.
\end{abstract}

Keywords: sustainable project management; project manager; project sustainability; skills; stimulus patterns

\section{Introduction}

Sustainability is recognised as one of the key areas of project management development today [1]. Although the developing literature on sustainability and project management focuses mainly on the sustainability of the project's deliverable and project management processes [2], a number of studies address the role of the project manager in the sustainability of projects and project management. For example, Hwang and Ng [3] concluded that "Today's project manager fulfils not only traditional roles of project management but also must manage the project in the most efficient and effective manner with 
respect to sustainability." [3], p. 273. In addition, the British Association for Project Management recognizes that "Project and Programme Managers are significantly placed to make contributions to Sustainable Management practices" [4], and the International Project Management Association included an explicit competence related to sustainability in their IPMA Individual Competence Baseline version 4 [5]. Although these views may certainly provide a stimulation for project managers to consider sustainability in their management of projects, Silvius and de Graaf [6] found that several factors and circumstances influence the project manager's intention of addressing sustainability.

As sustainability is considered a normative concept grounded in values underpinning individuals' attitudes and behaviours [7-9], the stimuli and inhibitors of sustainability considerations are likely to be perceived differently by different project managers. Following this reasoning, Silvius and Schipper [10] revealed three distinct patterns in the stimulation of sustainability-friendly behaviour of project managers: Intrinsically motivated, Taskdriven, and Pragmatic. These patterns were confirmed in the study of Marnewick et al. [11], which aimed to deepen the understanding of the project managers' characteristics that represented these three stimulus patterns. Regarding the distribution of the three patterns, this study showed that project managers are overwhelmingly classified as Intrinsically motivated. The Pragmatic and Task-driven patterns were closely tied for second and third place [11]. This distribution of patterns was irrespective of the personal demographics of the participating project managers and the type of projects they worked in. However, the analysis of the patterns showed that certain stimulus patterns were overrepresented in certain industries.

As the study of Marnewick, Silvius, and Schipper [11] was based on a relatively small sample of 101 respondents, this was mentioned as a limitation of the study. Another limitation was that the study sample was skewed towards organisational change and information technology (IT) projects, with only a small percentage of the respondents representing engineering and construction projects. It is these limitations that the study reported in this paper aimed to overcome. The study answered the call of Marnewick, Silvius, and Schipper [11] to follow up on the study with a wider population and investigate the results in more detail with regards to the impact of the industry on the stimuli patterns. The research questions of the study reported in this paper echo the questions used by Marnewick, Silvius, and Schipper [11]:

Research question 1: What is the dominant sustainability stimulus pattern of project managers?

Research question 2: To what extent do sustainability stimulus pattern groups of project managers relate with their personal characteristics and the context they work in?

By exploring the social-demographic and professional-related factors that the three stimulus patterns represent, the study aimed to contribute to the emerging body of knowledge on sustainable project management and specifically to understand the behaviour of project managers. The study addressed the gap that exists in current literature, where the focus is on the sustainability of the project's deliverable and project management processes.

The remainder of the article is organised as follows. The following section will position the emerging concept of sustainable project management (SPM) regarding the project manager's role and review the earlier studies on the stimulus of sustainability-friendly behaviour. Section 3 will present the research strategy and design developed for the study, including the sample's details. The study's findings will be presented in Section 4, followed by a discussion, after which the paper is concluded with answering the research questions and addressing the limitations of the study in Section 5.

\section{Literature Review}

This paragraph discusses the main concepts and variables of the study. In Section 2.1, we will describe the concept of SPM as it emerges from the literature. Section 2.2 addresses the role of the project manager in SPM, followed by the stimulus patterns found in earlier studies in Section 2.3. 


\subsection{Sustainable Project Management}

The role of project management in the sustainability performance of projects is well documented [10-13]. Integrating sustainability considerations into project management is therefore crucial for more sustainable projects. The growing body of literature that focuses on the intersection of sustainability and project management developed into the sustainability "school of thought" in project management [10] or simply "sustainable project management" (SPM) [2].

Early definitions of SPM focused on limiting the usage of resources in and pollution by projects. Examples of these definitions were provided by Deland [14]: “What is SPM? It is minimizing the resources that you and your team use to work a project from project initiation through close", and Cai et al. [15]: "SPM aims to apply the principle of meeting the needs of the day without compromising the benefits of future generations, to the construction industry by providing ways of buildings that use less virgin material and less energy, cause less pollution and less waste but still provide the benefits that construction projects have brought us throughout history". It may be argued that these definitions are limited in their scope, as they appear to miss out on the positive contribution a project can make to sustainability [12]. A definition that mentions both the positive and negative impacts of projects was provided by Tam (2010): "SPM is the promoting of positive and minimizing of negative sustainability impacts $[\ldots]$ within the process by which projects are defined, planned, monitored, controlled and delivered". The most elaborated definition of SPM was provided by Silvius and Schipper [8]: "Sustainable Project Management is the planning, monitoring and controlling of project delivery and support processes, with consideration of the environmental, economic and social aspects of the life-cycle of the project's resources, processes, deliverables and effects, aimed at realising benefits for stakeholders, and performed in a transparent, fair and ethical way that includes proactive stakeholder participation". This definition explicitly relates several concepts of sustainability and social responsibility, such as the Triple Bottom Line [16], life-cycle orientation, stakeholder orientation [17], and ethics, to project management.

From the literature on SPM, it appears that the relationship between sustainability and project management can be interpreted in two ways $[2,18]$. These two interpretations are characterized by [19] as:

- "Sustainability by the project": the sustainability of the deliverable or output that the project realizes.

- "Sustainability of the project": the sustainability of the delivery and management processes of the project.

Sustainability by the project implies that sustainability requirements are considered in the content-related aspects of the project [8], such as the specifications and design of the project's deliverable [20,21], materials used [22], benefits to be achieved [23,24], quality, and success criteria $[13,25]$. Studies on the integration of sustainability into project management that take this content-related perspective often focus on operationalizing the Triple Bottom Line by developing sets of indicators on the different perspectives [13,26-32].

Sustainability of the project applies a sustainability perspective to the processes of project management and delivery, such as the identification and engagement of stakeholders $[7,33]$, the process of procurement in the project [34], the development of the business case [23], the monitoring of the project [33], the identification and management of project risks [35], the communication in and by the project [36], and the selection and organisation of the project team [8].

It may be concluded that SPM relates most to the notion of sustainability of the project; however, [37] links sustainability of the project and by the project by arguing that the life-cycle orientation that sustainability implies requires that considering sustainability in the project management processes includes also considering the sustainability of the deliverables and effects of the project. 


\subsection{The Role of the Project Manager in Sustainable Project Management}

Despite lacking a clear definition $[38,39]$, it can be observed that the role of the project manager evolved from an internally oriented, planning- and control-focused guardian of the project plan [40] to a more externally oriented "front man" of the project that "sells and resells the project to stakeholders and communicates, shapes, and reshapes the relevant policies and guidelines" [39]. Today's project manager is not an administrator with a pre-defined task but a leader that also co-shapes the project [40]. In line with this, several authors $[24,41-43]$ concluded a central role for the project manager with regards to the consideration of sustainability in a project.

In addition, the latest versions of professional project management standards recognize the project manager's role in the sustainability of a project. For example, the IPMA Individual Competence Baseline version 4 [5] suggests that the project manager should be able to "assess the impact of the project on the environment and society" and that he/she "researches, recommends and applies measures to limit or compensate negative consequences" (Ibid.). Furthermore, the codes of ethics and professional conduct of both PMI [44] and IPMA [45] describe the professional responsibility of the project manager for sustainability. Silvius and Schipper [10], therefore, questioned whether the project manager can ignore a certain responsibility for applying this influence in order to make his/her project more sustainable. SPM is not about having responsibility but about taking responsibility [24].

Silvius and Schipper [8] concluded that SPM requires a mind shift of the project manager with regards to the way he or she sees his/her role: as the manager of the execution of a given task or as a co-shaper of that task. In SPM, the project manager realises that the project positively or negatively impacts society and takes action in trying to minimize negative impacts while boosting positive contributions [8].

Despite the growing attention for the role that project managers can and should take regarding the sustainability and societal impacts of their projects, Økland [46] still observed a gap between the literature and what is carried out in practice. The project manager is observed to be reluctant in using the influence he or she has [6]. For example, the fear that addressing sustainability might harm their relationship with the project owner and other key stakeholders provided a hurdle for the project managers in the study.

\subsection{Stimulus Patterns}

Silvius and Schipper [10] studied the different subjective perceptions of the stimulus that project managers experience to address sustainability in their projects and identified three distinct stimulus patterns: Intrinsically motivated, Task-driven, and Pragmatic.

Intrinsically motivated project managers are stimulated to address sustainability because they care about nature, the planet, and the future and because they feel that caring for sustainability is something they should do. The characteristics of the project, or the opinion of others, do not play a prominent role. This group of project managers is intrinsically motivated for sustainability and will do what they consider the "right thing". The participants that were classified in this pattern showed themselves not very sensitive to rewards or status, as with frequent motivation that they do not care about rewards or image. In addition, the opinion of the professional bodies (PMI and IPMA) and their codes of conduct do not provide much stimulation. Even the project assignment does not provide much inspiration for this group of respondents.

A contrasting pattern of stimulus was labelled Task-driven. The project managers classified in this pattern indicated being willing to address sustainability if it is part of the project's requirements or objectives, when the client asks for it, or when they are rewarded for it. This group of project managers can be stimulated to address sustainability by external pressure or rewards. Furthermore, the importance that key stakeholders (project board/executive board/management) and customers attach to sustainability provides a strong stimulus for this group of project managers. The Task-driven project managers showed themselves not very sensitive to the practical side of addressing sustainability. 
The Pragmatic project managers took an instrumental approach to address sustainability. They were not strongly self-motivated but would address it when they see a good application for sustainability. Many of the project managers in this group characterized themselves as being result-oriented. In addition, team- and people-orientation showed to be important for this group of respondents.

Marnewick, Silvius, and Schipper [11] reported a quantitative study aimed to create a more in-depth understanding of the three stimulus patterns. In this study, most participating project managers $(72.3 \%)$ were classified as Intrinsically motivated. The Pragmatic $(12.9 \%)$ and Task-driven patterns $(10.9 \%)$ were closely tied for second and third place. The study also strengthened the confidence in the three distinct stimulus patterns, as two of the three patterns showed a higher internal consistency than the consistency of the whole sample. The study also showed negative correlations between the patterns, which implied that the patterns are exclusive and do not support or contribute to each other.

As the study aimed to increase the understanding of the project managers' backgrounds that represent the three stimulus patterns, the differences in demographic and descriptive variables of the three groups were analysed. Regarding the industry representation, the study of Marnewick, Silvius, and Schipper [11] found an overrepresentation of the Task-driven pattern in "high governance" industries such as government, public administration, and financial services. The Pragmatic pattern peaked in the IT and communication sector, whereas the Intrinsically motivated pattern followed the entire sample's industry representation.

Regarding the types of project, Silvius and Schipper [10] suggested that the Taskdriven pattern might be strongest in "hard" projects (infrastructure, real estate, and construction), whereas the Intrinsically motivated pattern might be strongest in "soft" projects (organisational change, information systems or technology, and research and development). However, the study of Marnewick, Silvius, and Schipper [11] did not confirm this, with Intrinsically motivated being the most important stimulus pattern in all types of projects. The study of Marnewick, Silvius, and Schipper [11] did also not show a remarkable difference in the distribution of the three patterns over the different age groups in the sample.

Given the limited insights into the characteristics of the populations of the three stimulus patterns that the earlier studies provided, the study reported in this article aimed to fill this gap in the literature. We hypothesised that:

Hypothesis 1 (H1). The Intrinsically motivated pattern is the most prominent stimulus pattern.

Hypothesis 2 (H2). There are differences in how sustainability stimulus patterns relate to project manager's socio-demographic characteristics.

\section{Materials and Methods}

Following the study of Marnewick, Silvius, and Schipper [11], the study reported in this article also applied a quantitative approach with a survey-based data collection strategy.

\subsection{Data Collection}

This survey was carried out using an online self-administered questionnaire between 24 September and 2 November 2020. A convenience sample of 47 project managers and team members enrolled in a project management post-graduation course first took the survey to obtain fast feedback about any potential issue. As no issues were reported, on the one hand, the respondents were invited to forward the survey to other project managers and team members (snowball sampling). On the other hand, the survey was also put to circulation online by Associação Portuguesa de Gestão de Projetos (APOGEP), a national association of project managers in Portugal. As a result, 516 responses were obtained, of which 433 were complete ( $83.9 \%$ completion rate). When one assumes a total population of project managers of over 1 million in the regions that were included in the sample, the sample provides a confidence interval of $4.71 \%$ at a $95 \%$ confidence level. All procedures 
were in accordance with the ethical standards of the institutional and/or national research committee and with the 1964 Helsinki Declaration and its later amendments or comparable ethical standards. Informed consent was obtained from all individual participants involved in the study.

\subsection{Questionnaire Development}

The questionnaire was structured into two sections. The first section included socialdemographic and professional items; the second section consisted of the instrument to assess the sustainability stimulus patterns, comprising 66 pairwise comparison questions.

\section{Social-demographic and professional-related items}

The first section of the questionnaire included the following items, which used nominal scales: gender (female; male), age group (less than 35 years old; more than 35 years old), educational background (engineering; economics and management; architecture; health; other), educational degree (MSc or higher; BSc or lower), industry (construction; utilities; engineering, research, and development; financial services; other services; information technologies; retail and marketing; manufacturing and mining; other), types of project (infrastructure and construction; engineering and installation; information technologies; organisational change; research and development; services and other), work locations (Portugal; other European location; Africa/Asia; America; other), project budget (less than 1 million dollars; more than 1 million dollars), most frequent project model (waterfall; agile; hybrid), and project management certification status (with certification; without certification).

\section{Instrument for sustainability stimulus patterns assessment}

To associate a pattern-Pragmatic, Intrinsically motivated, and Task-driven-to each participant, the instrument developed by Marnewick, Silvius, and Schipper [11] was applied. Such an instrument reuses the highest-scoring 12 statements (Table 1) concerning what stimulates considering sustainability as suggested in the exploratory study by Silvius et al. (2017), which were found suitable to classify each respondent in one of the three patterns (Table 1).

Table 1. Defining statements used in the data collection instrument.

\begin{tabular}{cl}
\hline Number & \multicolumn{1}{c}{ Statement } \\
\hline 1 & I find it important that we treat the earth well \\
2 & My team has the knowledge, skills, or abilities to do something with it \\
3 & Customers ask about it and/or find it interesting \\
4 & I can see the results of my work \\
5 & It is part of the goals and/or contract \\
6 & I find it important that future generations can live a normal life \\
7 & It suits the culture of the company \\
8 & I can give it shape and/or have my own ideas about it \\
9 & I think it is something that you should do \\
10 & My project team is interested in it and/or likes it \\
11 & There is an impulse from the company to address it \\
12 & Key people find it important (project board/executive board/management) \\
12 & I find it important that we treat the earth well
\end{tabular}

As described in Marnewick, Silvius, and Schipper [11], the instrument uses 66 pairwise comparison questions as a result of a pairwise comparison test design that paired each statement with the other 11 statements. The instrument determines a "fit" score for each respondent as the percentage of congruence of their ranking of the 12 statements with each pattern's "perfect" ranking. The three fit scores are then presented in a spider web graphic for each respondent. Finally, each respondent is classified as pragmatic, intrinsically motivated, or task-driven according to the highest fit score. 
As noted by Marnewick, Silvius, and Schipper [11], even a respondent with a 100\% fit score in a pattern will have some fit with the two other patterns, which is explained by some degree of correlation amongst the patterns.

\subsection{Data Analysis}

Descriptive statistics were used to understand participants' characteristics and item analyses. Analyses on psychometric properties included internal consistency. The Chisquare test $\left(\chi^{2}\right.$, commonly used for testing relationships between categorical variables; being the null hypothesis that no relationship exists on the categorical variables in the population; they are independent), student $t$-test ( $t$, inferential statistical test that determines whether there is a statistically significant difference between the means in two unrelated groups), and ANOVA ( $F$, or analysis of variance are statistical models and their associated estimation procedures used to analyse the differences among means) [47] were used to compare the patterns of sustainability stimulus according to sociodemographic factors and their distribution. Pearson correlations were used to evaluate associations between concepts. Internal consistency was evaluated by Cronbach's alpha. A $p$ value of less than 0.05 was considered significant. Pearson correlations and Cronbach's alpha were also used in Marnewick and colleagues' study [11]. All the analyses were conducted using IBM SPSS 27.0 (IBM Corp., Armonk, NY, USA).

\subsection{Participants}

Most of the respondents were male ( $279 \%$ or $64.4 \%)$, less than 35 years old ( $238 \%$ or $54.9 \%)$, and held an MSc degree or above ( $274 \%$ or $63.3 \%)$-Figure 1 cross-tabulates the respondents' age and gender by education degree (Figure 1).

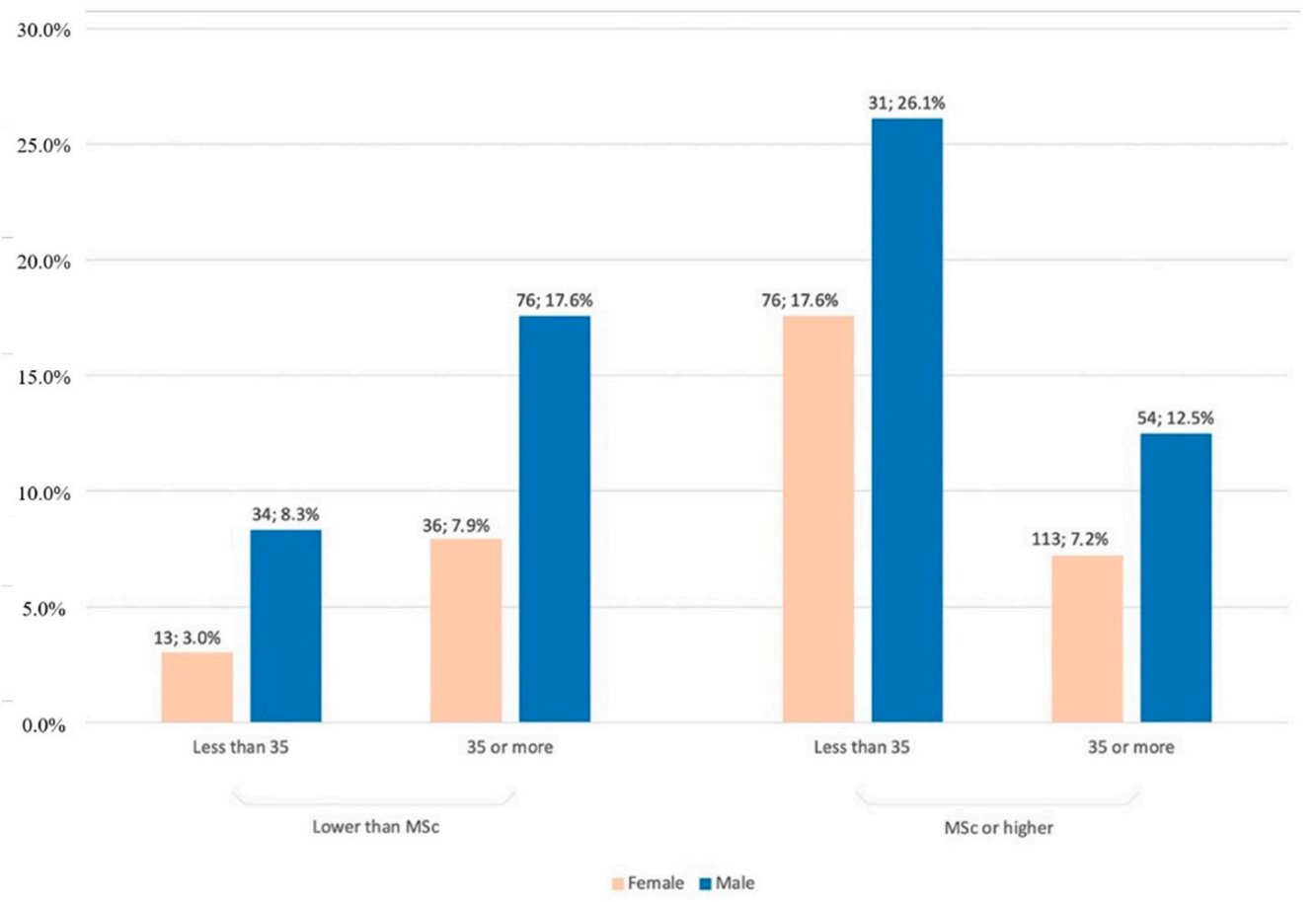

Figure 1. Gender, age, and education degree distribution of the sample.

Figure 2 shows the educational background area of the respondents. About two-thirds of the sample came from the engineering area $(289 \%$ or $66.7 \%)$, followed by economics and management ( $58 \%$ or $13.4 \%)$.

The respondents practice project management in different industries, following the distribution of Figure 3. The most represented industries are manufacturing/mining $(85 \%$ or $19.8 \%$ ) and other services $(82 \%$ or $19.1 \%)$, which include consulting, legal, hu- 
man resources, and logistics, followed by information technologies ( $68 \%$ or $15.8 \%)$, the construction industry ( $47 \%$ or $10.9 \%)$, and utilities ( $46 \%$ or $10.7 \%)$.

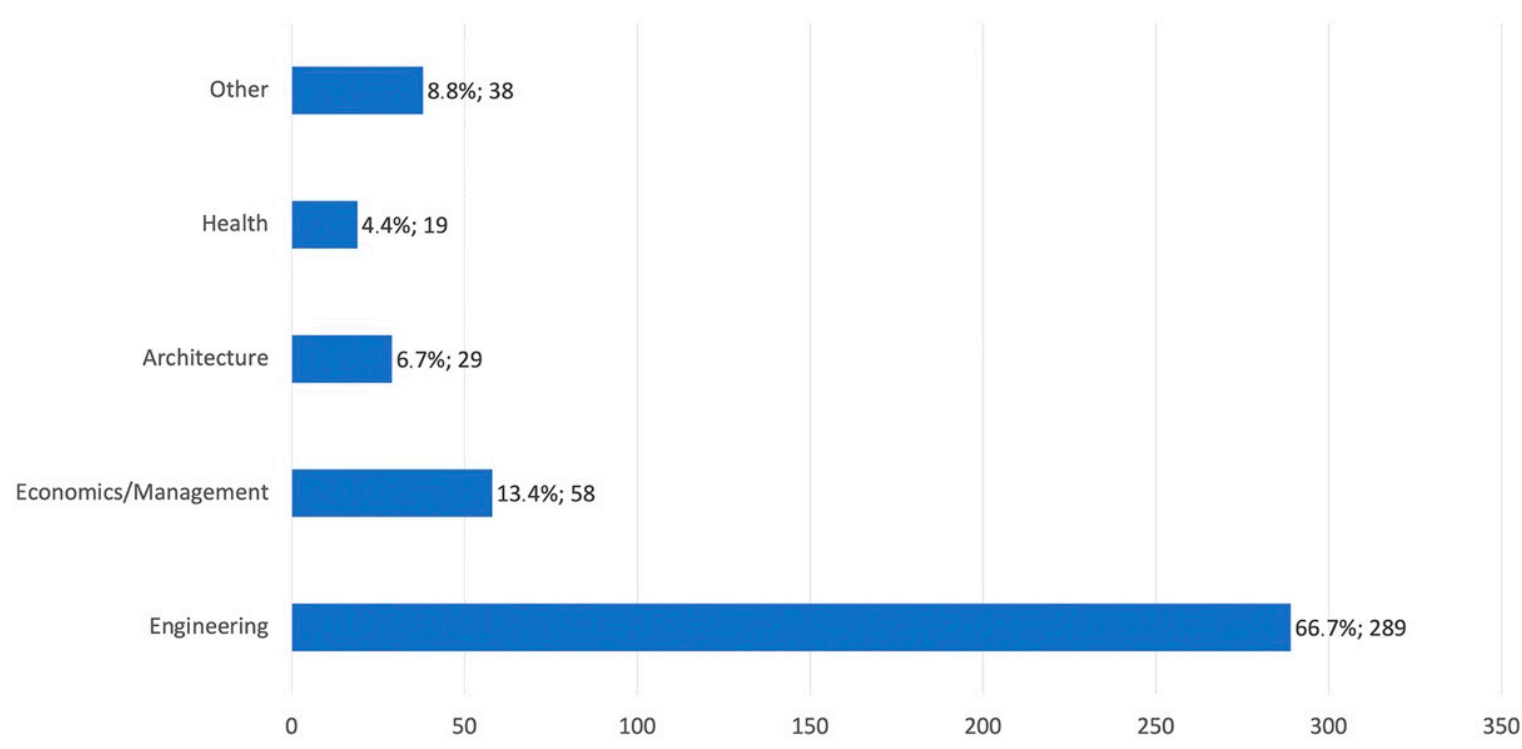

Figure 2. Educational area representation.

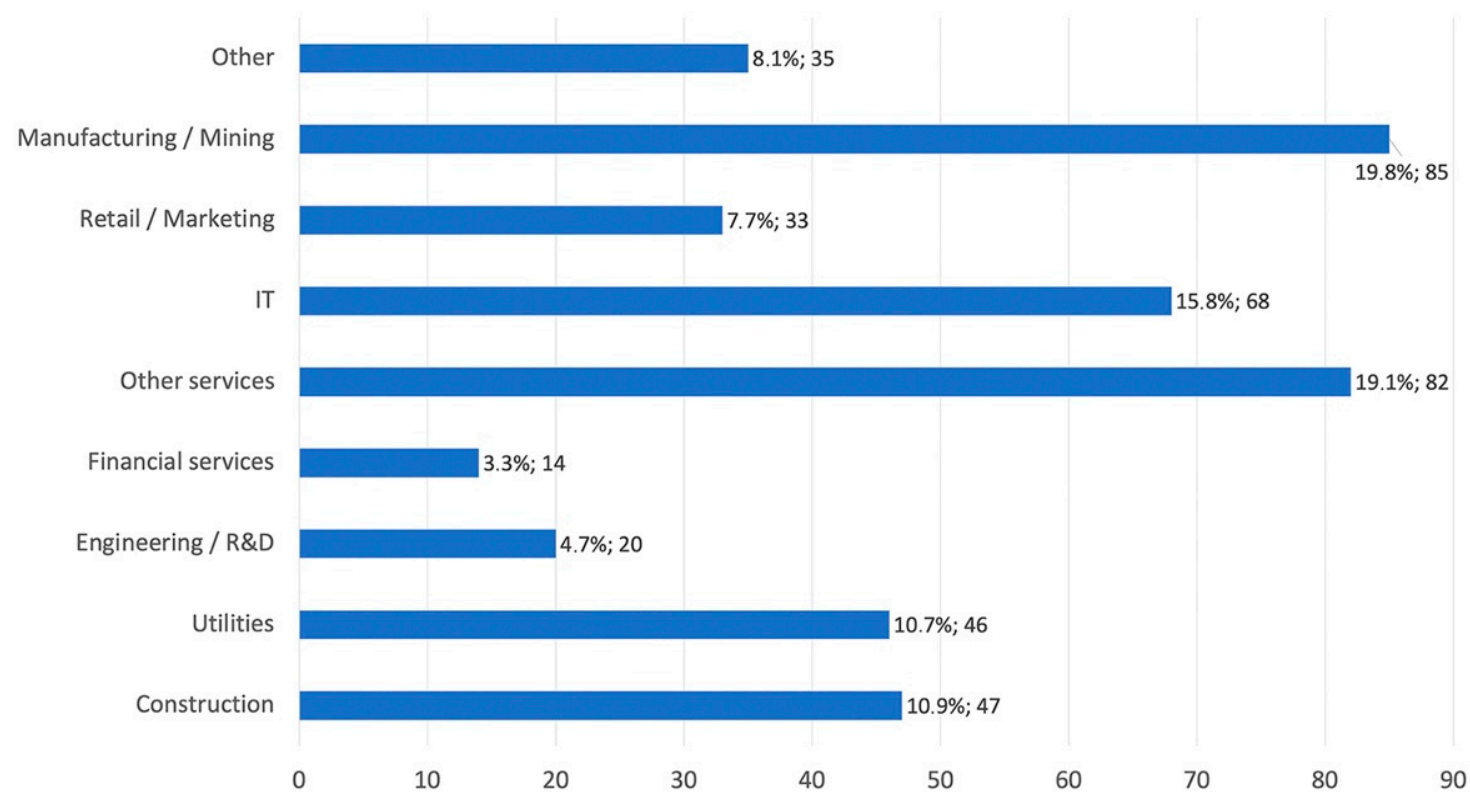

Figure 3. Industry representation.

The participants were asked to indicate the type of projects they are mostly engaged in, which resulted in Figure 4. Engineering/installation is the most represented type of project $(28.6 \%)$ and, together with infrastructure/construction, account for $48.7 \%$ of the respondents. This was expected, considering that most of the respondents come from the engineering field-civil engineering in particular; therefore, the sample is somehow biased towards engineering and building projects. IT projects are also well represented (87 respondents or $20.1 \%$ ).

The majority of the respondents work in Portugal (74.4\%), but $25.6 \%$ participate only in projects abroad. From the total sample, 102 respondents $(23.6 \%)$ work on projects abroad, mainly in Europe. Figure 5 shows the geographic areas where the respondents' projects take place. 
Concerning project size, 248 respondents (57.3\%) usually engage in projects with budgets below 1 million dollars. Respondents were also questioned about the dominant project model of the projects they participate in; results show that $45.0 \%$ use the waterfall model, $16.7 \%$ agile models, and $38.3 \%$ hybrid configurations. To complete the sample characterisation, 39 respondents $(9.0 \%)$ are certified by the Project Management Institute (PMI), the International Project Management Association (IPMA), or others.

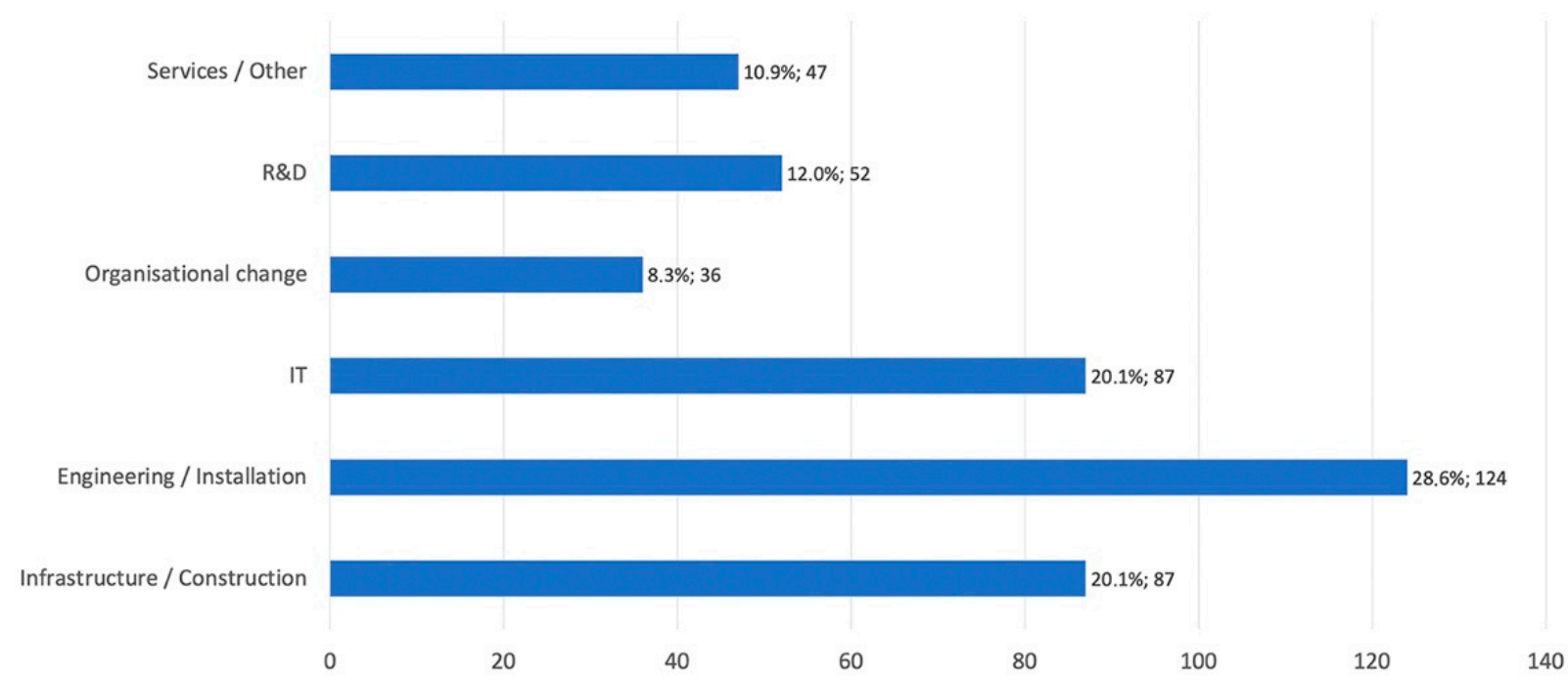

Figure 4. Types of projects.

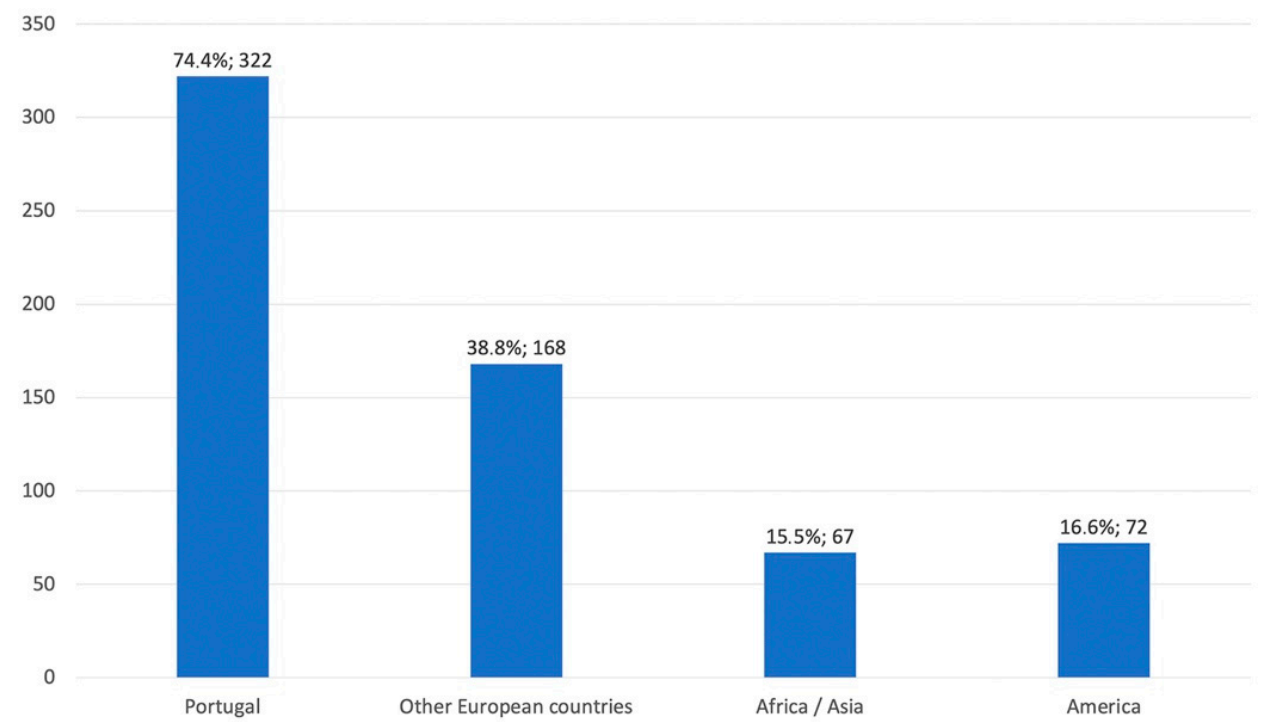

Figure 5. Geographic location of projects.

\section{Results}

\subsection{Stimuli Analysis}

With the decision rule of assigning one of the three stimulus patterns to each respondent according to the highest fit score, three groups of respondents were created, resulting in that 268 or $61.9 \%$ were classified as Intrinsically motivated, whereas $91(21.0 \%)$ as Pragmatic, and $74(17.1 \%)$ as Task-driven (Figure 6).

The answers to the pairwise questions provided by the groups of respondents are consistent, as the Cronbach's alpha for each group is above 0.70 (Table 2). 


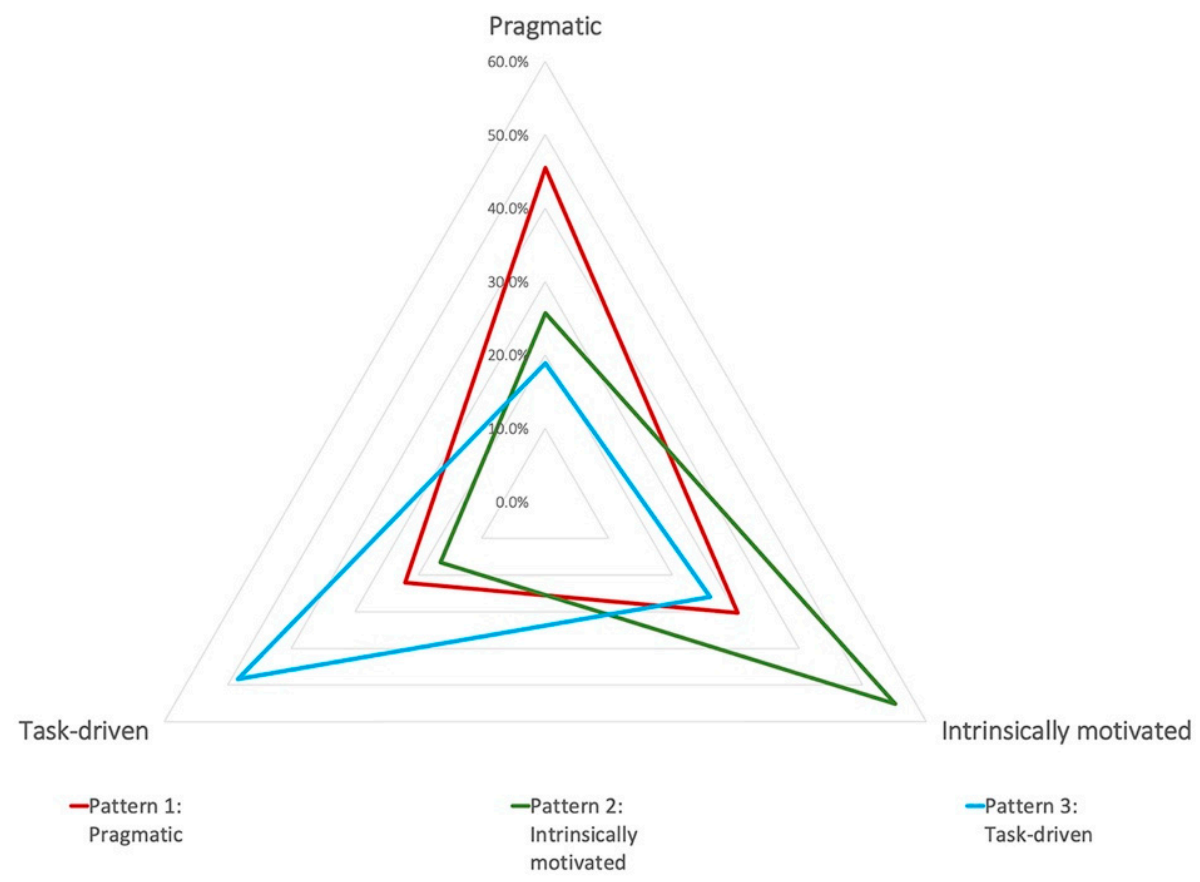

Figure 6. Average fit scores for each group of respondents.

Table 2. Cronbach's alpha coefficient per stimulus pattern group.

\begin{tabular}{cc}
\hline Group & Cronbach's Alpha \\
\hline Pragmatic & 0.76 \\
Intrinsically motivated & 0.82 \\
Task-driven & 0.86 \\
Total sample & 0.81 \\
\hline
\end{tabular}

Table 2 also shows that two of the three pattern groups show a higher internal consistency than the total sample. Following Marnewick, Silvius, and Schipper [11], this can be seen as another confirmation of the three stimulus patterns. In line with this, Table 3 shows that the three pattern groups also correlated negatively with each other, which implies that the three patterns do not support or contribute to each other. These correlations are statistically significant, in particular between the intrinsically motivated and the task-driven patterns $(r=-0.611)$. Correlations are weaker between the pragmatic and the task-driven patterns $(r=-0.210)$ and between the pragmatic and the intrinsically motivated patterns $(r=-0.323)$.

Table 3. Pearson correlations between stimulus patterns.

\begin{tabular}{cccc}
\hline & Pragmatic & Intrinsically Motivated & Task-Driven \\
\hline Pragmatic & 1.00 & $-0.32^{* *}$ & $-0.21^{* *}$ \\
Intrinsically motivated & $-0.32^{* *}$ & 1.00 & $-0.61^{* *}$ \\
Task-driven & $-0.21^{* *}$ & $-0.61^{* *}$ & 1.00 \\
\hline
\end{tabular}

** Correlation is significant at the 0.01 level (2-tailed).

\subsection{Differences in Sustainability Stimulus Patterns}

Table 4 displays descriptive socio-demographic statistics by stimulus pattern. Figures 7-10 depict these statistics for educational background, industry, project type, and budget size. 
Table 4. Descriptive socio-demographic statistics.

\begin{tabular}{|c|c|c|c|c|}
\hline Items & Pragmatic & Intrinsically Motivated & Task-Driven & Total Sample \\
\hline \multicolumn{5}{|l|}{ Gender } \\
\hline Male & $68.1 \%$ & $63.8 \%$ & $62.2 \%$ & $64.4 \%$ \\
\hline Female & $31.9 \%$ & $36.2 \%$ & $37.8 \%$ & $35.6 \%$ \\
\hline \multicolumn{5}{|l|}{ Age } \\
\hline Less than 35 years old & $36.3 \%$ & $45.5 \%$ & $54.1 \%$ & $45.0 \%$ \\
\hline 35 or more years old & $63.7 \%$ & $54.5 \%$ & $45.9 \%$ & $55.0 \%$ \\
\hline \multicolumn{5}{|l|}{ Education degree } \\
\hline Bachelor's degree or less & $56.0 \%$ & $64.9 \%$ & $66.2 \%$ & $63.3 \%$ \\
\hline Master's degree or more & $44.0 \%$ & $35.1 \%$ & $33.8 \%$ & $36.7 \%$ \\
\hline \multicolumn{5}{|l|}{ Education area } \\
\hline Engineering & $65.9 \%$ & $68.7 \%$ & $60.8 \%$ & $66.7 \%$ \\
\hline Economics/Management & $12.1 \%$ & $11.6 \%$ & $21.6 \%$ & $13.4 \%$ \\
\hline Architecture & $8.8 \%$ & $5.2 \%$ & $9.5 \%$ & $6.7 \%$ \\
\hline Health & $6.6 \%$ & $4.5 \%$ & $1.4 \%$ & $4.4 \%$ \\
\hline Other & $6.6 \%$ & $10.1 \%$ & $6.8 \%$ & $8.8 \%$ \\
\hline \multicolumn{5}{|l|}{ Industry } \\
\hline Construction & $6.6 \%$ & $13.4 \%$ & $6.8 \%$ & $10.9 \%$ \\
\hline Utilities & $7.7 \%$ & $11.6 \%$ & $10.8 \%$ & $10.6 \%$ \\
\hline Engineering/R\&D & $3.3 \%$ & $4.5 \%$ & $6.8 \%$ & $4.6 \%$ \\
\hline Financial services & $3.3 \%$ & $3.4 \%$ & $2.7 \%$ & $3.2 \%$ \\
\hline Other services & $19.8 \%$ & $20.5 \%$ & $12.2 \%$ & $18.9 \%$ \\
\hline IT & $17.6 \%$ & $16.4 \%$ & $12.2 \%$ & $15.9 \%$ \\
\hline Retail/Marketing & $7.7 \%$ & $7.1 \%$ & $9.5 \%$ & $7.6 \%$ \\
\hline Manufacturing/Mining & $22.0 \%$ & $16.0 \%$ & $32.4 \%$ & $20.1 \%$ \\
\hline Other & $12.1 \%$ & $7.1 \%$ & $6.8 \%$ & $8.1 \%$ \\
\hline \multicolumn{5}{|l|}{ Type of project } \\
\hline Infrastructure/Construction & $15.4 \%$ & $22.0 \%$ & $18.9 \%$ & $20.1 \%$ \\
\hline Engineering/Installation & $33.0 \%$ & $25.7 \%$ & $33.8 \%$ & $28.6 \%$ \\
\hline IT & $19.8 \%$ & $21.6 \%$ & $14.9 \%$ & $20.1 \%$ \\
\hline Organisational change & $11.0 \%$ & $6.7 \%$ & $10.8 \%$ & $8.3 \%$ \\
\hline$R \& D$ & $11.0 \%$ & $11.6 \%$ & $14.9 \%$ & $12.0 \%$ \\
\hline Services/Other & $9.9 \%$ & $12.3 \%$ & $6.8 \%$ & $10.9 \%$ \\
\hline \multicolumn{5}{|l|}{ Budget } \\
\hline Less than 1 million dollars & $64.8 \%$ & $54.1 \%$ & $59.5 \%$ & $57.3 \%$ \\
\hline More than 1 million dollars & $35.2 \%$ & $45.9 \%$ & $40.5 \%$ & $42.7 \%$ \\
\hline \multicolumn{5}{|l|}{ Projects' geographical location } \\
\hline Portugal & $44.9 \%$ & $53.8 \%$ & $50.0 \%$ & $51.2 \%$ \\
\hline Other European countries & $29.0 \%$ & $25.6 \%$ & $27.8 \%$ & $26.7 \%$ \\
\hline Asia/Africa & $11.6 \%$ & $9.9 \%$ & $12.0 \%$ & $10.7 \%$ \\
\hline America & $14.5 \%$ & $10.7 \%$ & $10.2 \%$ & $11.4 \%$ \\
\hline \multicolumn{5}{|l|}{ Project model } \\
\hline Waterfall & $51.6 \%$ & $45.5 \%$ & $35.1 \%$ & $45.0 \%$ \\
\hline Agile & $13.2 \%$ & $18.3 \%$ & $14.9 \%$ & $16.6 \%$ \\
\hline Hybrid & $35.2 \%$ & $36.2 \%$ & $50.0 \%$ & $38.3 \%$ \\
\hline \multicolumn{5}{|l|}{ Certification } \\
\hline Professional certification & $7.7 \%$ & $10.8 \%$ & $4.1 \%$ & $9.0 \%$ \\
\hline No certification & $92.3 \%$ & $89.2 \%$ & $95.9 \%$ & $91.0 \%$ \\
\hline
\end{tabular}




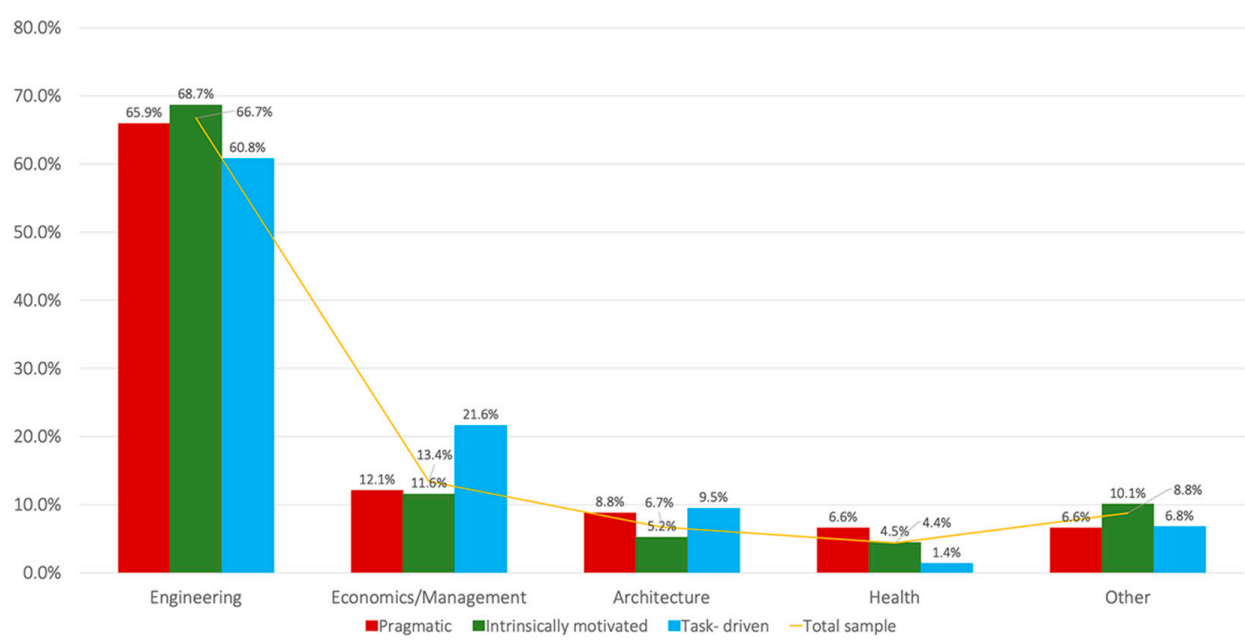

Figure 7. Educational background representation per stimulus pattern group.

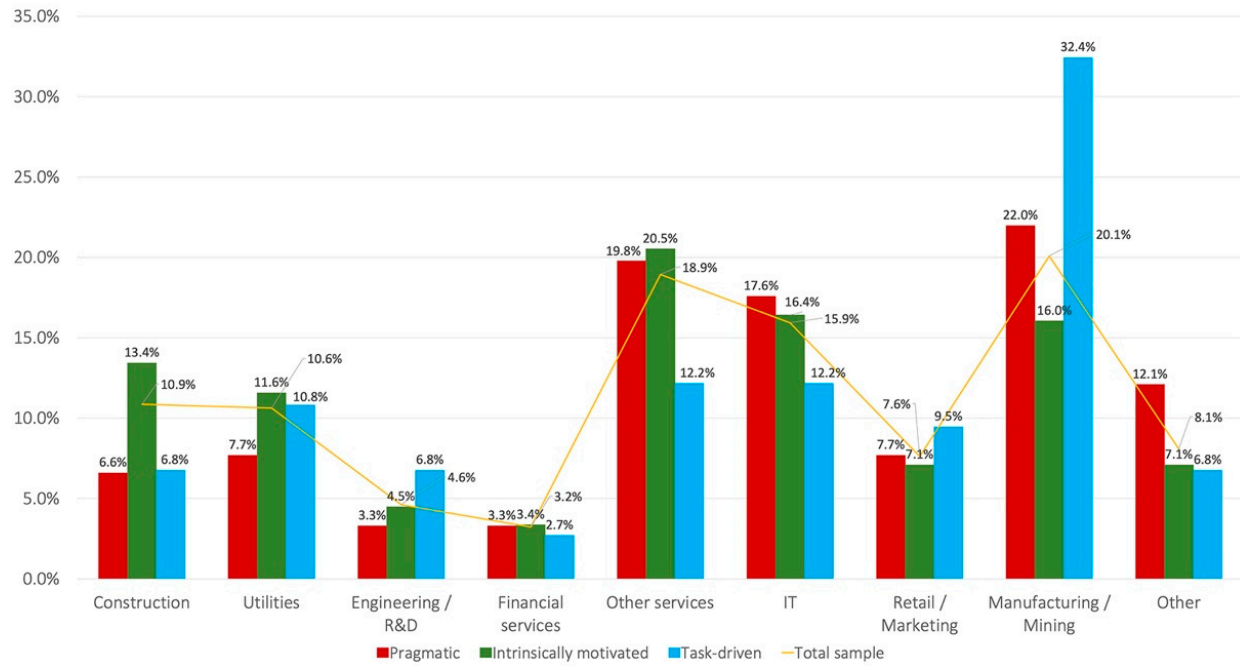

Figure 8. Industry representation per stimulus pattern group.



Figure 9. Project-type representation per stimulus pattern group. 


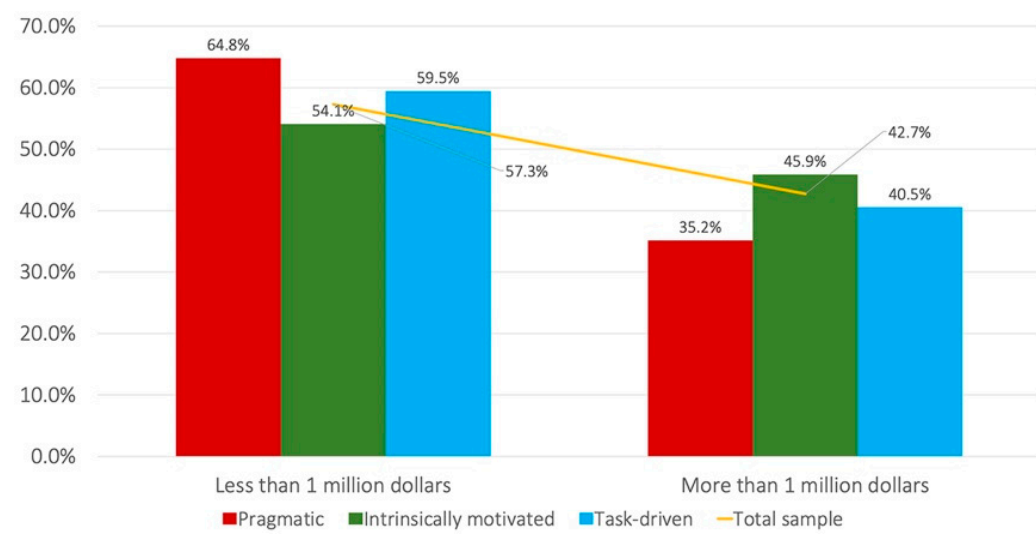

Figure 10. Project budget size representation per stimulus pattern group.

With regards to gender, the distribution in the three pattern groups does not differ much from the total sample. Male respondents were slightly overrepresented in the Pragmatic pattern, but the differences are small. The age distribution of the pattern groups shows that participants younger than 35 years are overrepresented in the Task-driven pattern; in contrast, participants of 35 and older were overrepresented in the Pragmatic pattern. A potential explanation for this can be the different stages of career development that the different age groups are in. However, a further study of this fell beyond the scope of our study.

With regards to education, the Masters' level is overrepresented in the Pragmatic pattern. Again, a potential explanation for this might be the stage of career development, but this would require further study. Figure 7 presents the representation of educational backgrounds in the three stimulus pattern groups. Most outstanding in this representation is the overrepresentation of the Economics/Management background in the Task-driven pattern.

The industry representation per stimulus group is depicted in Figure 8, which shows that there are stimulus patterns overrepresented in certain industries. For example, the Task-driven group respondents peak (32.4\%) in the manufacturing/mining industry; in contrast, the Intrinsically motivated group of respondents closely follow the total sample's curve, reflecting its dominance in the total sample.

Figure 9 presents the representation of different project types in the different stimulus groups. This shows that the engineering/installation type of project is overrepresented in both the Task-driven and the Pragmatic pattern, with IT projects showing an underrepresentation in the Task-driven pattern. This is in line with the hypothesis posed by Silvius and Schipper (2020).

Regarding project budget size (Figure 10), the projects with a budget of less than 1 million dollars showed an overrepresentation of the Pragmatic pattern.

\subsection{Analysis of Significance}

This section describes the results obtained from testing correlations and differences between sustainability stimulus patterns regarding respondents' personal characteristics and the context they act in professionally.

The three sustainability stimulus pattern's groups (Pragmatic, Intrinsically motivated, and Task-driven) were compared with the respondents' personal characteristics-gender, age, educational degree, and whether the respondent is certified — but no significant statistical differences were found. They were also compared with project models—waterfall, agile, and hybrid — and region where projects occur-Portugal, other European countries, Asia/Africa, and America-finding no significant statistical differences either. However, some significant statistical differences were found regarding other variables, as reported below.

There are significant statistical differences for the Pragmatic respondents' educational area $\left[F(4,427)=2.96 ; p=0.020 ; \eta^{2}=0.03\right]$ : the highest value occurs in health $(0.39)$, followed by architecture and other areas $(0.32)$, economics and management $(0.30)$, and engineering 
(0.29). With this regard, there are also significant statistical differences for Task-driven respondents $\left[F(4,427)=2.42 ; p=0.048 ; \eta^{2}=0.02\right]$ : the highest value occurs in economics and management (0.39), followed by engineering (0.23), architecture (0.22), and health and other areas (0.19).

The industry representation of the Task-driven group showed statistical significance in $\left[F(5,426)=2.25 ; p=0.048 ; \eta^{2}=0.03\right]$ : the highest value occurs in retail/marketing (0.31), followed by manufacturing/mining (0.26), engineering/R\&D-research and development and IT-information technology industries (0.24), other industries (0.23), utilities and construction (0.22), financial services (0.19), and other services (0.18).

Significant differences were found in the representation of the stimulus patterns concerning project type. For the Intrinsically motivated respondents $[F(8,423)=2.86 ; p=0.004$; $\left.\eta^{2}=0.05\right]$, the highest value occurs in IT $(0.48)$, followed infrastructure/construction and services (0.47), R\&D (0.43), engineering/installation (0.42), and organisational change projects $(0.41)$. For the Task-driven respondents $\left[F(8,423)=2.81 ; p=0.017 ; \eta^{2}=0.03\right]$, the highest value occurs in organisational change projects $(0.29)$, followed by engineering and R\&D (0.24), IT (0.23), infrastructure/construction (0.21), and services (0.17).

The distribution of patterns per budget size is represented in Figure 10. Significant statistical differences exist in Pragmatic respondents regarding the project budget $[t(430)=2.21 ; p=0.027 ; d=0.14]$ : the highest value occurs in respondents that work with projects with budgets below 1 million dollars (0.31), whereas the average is 0.28 for projects above 1 million dollars.

\section{Discussion}

The study's findings in this paper complement the findings of Marnewick, Silvius, and Schipper [11]. The representation of the three patterns in both studies is presented in Table 5.

Table 5. Representation of the stimulus pattern groups in the total population.

\begin{tabular}{ccc}
\hline Pattern Group & Study of Marnewick et al. (2019) * & This Study \\
\hline Pragmatic & $12.9 \%$ & $21.0 \%$ \\
Intrinsically motivated & $72.3 \%$ & $61.9 \%$ \\
Task-driven & $10.9 \%$ & $17.1 \%$ \\
\hline
\end{tabular}

* In this study, $3.9 \%$ of participants could not be allocated to one of the patterns.

Hypothesis H1, concerning that Intrinsically motivated pattern would be the most prominent stimulus pattern was confirmed. The distribution of stimulus patterns that the study reported in this paper found bears a strong resemblance with the study of Marnewick, Silvius, and Schipper [11]. The Intrinsically motivated pattern showed up as the most prominent stimulus pattern, although the representation is somewhat lower than in the earlier study. Again, the Pragmatic and Task-driven patterns showed to be closely tied for place two. Indications for the strong representation of the Intrinsically motivated pattern were also found in the studies of Poon and Silvius [48] and Marnewick, Silvius, and Schipper [11], although the methodology used in these studies does not aim to reveal the representation of patterns in the larger population of project managers. Nevertheless, the recurring finding that most project managers are Intrinsically motivated to consider sustainability is a clear indication that project managers' motivation is not an obstacle for SPM.

The position of Intrinsically motivated as the most prominent stimulus pattern is also confirmed in the analysis of the second and third stimulus patterns (Table 6), in which Intrinsically motivated also appears as the second stimulus pattern of Pragmatic and Task-driven pattern groups, again confirming the findings of Marnewick, Silvius, and Schipper [11]. 
Table 6. Preferred sustainability stimulus order.

\begin{tabular}{ccccc}
\hline \multirow{2}{*}{ Original Stimulus } & \multicolumn{2}{c}{ Second Stimulus } & & Third Stimulus \\
\cline { 2 - 5 } & Study of Marnewick et al. (2019) & This Study & Study of Marnewick et al. (2019) & This Study \\
\hline Intrinsically motivated & Task-driven & Pragmatic & Pragmatic & Task-driven \\
\hline Pragmatic & $\begin{array}{c}\text { Intrinsically } \\
\text { motivated }\end{array}$ & $\begin{array}{c}\text { Intrinsically } \\
\text { motivated }\end{array}$ & Task-driven & Task-driven \\
\hline Task-driven & $\begin{array}{c}\text { Intrinsically } \\
\text { motivated }\end{array}$ & $\begin{array}{c}\text { Intrinsically } \\
\text { motivated }\end{array}$ & Pragmatic & Pragmatic \\
\hline
\end{tabular}

In line with the study of Marnewick, Silvius, and Schipper [11], many demographic variables in this study - gender, educational degree, age, project management certification, and project model — did not show a significant difference in the representation of the three stimulus patterns. Therefore, for all sustainability patterns and these socio-demographic characteristics, hypothesis $\mathrm{H} 2$ is not confirmed. However, the hypothesis is confirmed, though with small differences, amongst pragmatic and task-driven respondents and educational area, intrinsically motivated and task-driven respondents and project type, and pragmatic respondents and project budget size. This supports the conclusion that "the type of pattern that determines a project manager's behaviour, is a personal trait" [11]. A similar conclusion was found in the few studies that focused on managers' sustainability-friendly behaviour within an organizational environment. For example, Cordano and Frieze [49] and Ruepert et al. [50] found that the personal attitude of the manager played a significant role in the adoption of sustainability-friendly behaviour.

Of the demographic variables that did show a significant difference, industry, educational area, type of project, and budget, the study found an overrepresentation of the Task-driven pattern mostly in manufacturing/mining and engineering/R\&D. This is more in line with the hypothesis posed by Silvius and Schipper [10], which suggest that the Task-driven pattern may be more common in the "hard" types of projects.

\section{Conclusions}

The study reported in this paper aimed to contribute to understanding the patterns of stimulus that stimulate project managers to consider sustainability in their projects. Building upon earlier studies by [10] and [11], this study focused on the questions "What is the dominant sustainability stimulus pattern of project managers?" and "To what extent do sustainability stimulus patterns' groups of project managers relate with their personal characteristics and the context they work in?".

Regarding the first question, this study found that the most dominant stimulus pattern is Intrinsically motivated, in which $61.9 \%$ of our sample was classified, with the Pragmatic $(21.0 \%)$ and Task-driven $(17,1 \%)$ patterns closely tied for second and third place. This confirms the findings of [11], which also reported Intrinsically motivated as the dominant stimulus pattern. The fact that all respondents could be classified in one of the three stimulus patterns again strengthens the confidence in these three patterns that were first revealed by [10].

With the second research question, the study aimed to explore the three stimulus patterns' social-demographic and professional-related characteristics. On this question, the study showed a dualistic result. On the one hand, many social-demographic variables, such as gender, age, education, certification, project model, and geographical region, did not show a significantly different representation over the three stimulus patterns. This supports the conclusion found by [11] that "the type of pattern that determines a project manager's behaviour, is a personal trait". However, our findings did indicate that the projects' industry and the type of projects did make a difference. The overrepresentation of the Task-driven stimulus pattern in the manufacturing/mining and engineering/R\&D industries and the engineering/installation type of projects may indicate a confirmation of the hypothesis posed by [10] that the Task-driven pattern may be more common in 
the "hard" types of projects. A direction for further studies would be a deepening of the reasons why the "hard" types of projects are more related to the Task-driven pattern of sustainability stimulus and whether the form of contract in construction and engineering projects is of influence on this.

The contribution the study made is that it confirmed indications about the representation of the three stimulus patterns in the population of project managers that were found by explorative and smaller sample studies. With the Intrinsically motivated pattern now being established as the dominant stimulus pattern, further studies can now follow up on this. Another direction for further studies is, therefore, the investigation into the factors that shape the motivation of managers for sustainability, or the barriers intrinsically motivated project managers experience in acting "sustainably" in their role. In addition, the impact of considering sustainability in the practices of project management and the behaviour of the project manager may be explored further.

Limitations of the study are provided by the methodology, which does not allow for further investigation of the "why" of the indicated answers. Acknowledging that sustainability by the project manager is found to be a personal treat based on the individual's personal attitude towards sustainability, what factors determine or influence this attitude? This, therefore, also offers another opportunity for further research.

Author Contributions: Conceptualization, J.M. and G.S.; formal analysis, J.M., G.S., C.S.S., and Â.L.; methodology, J.M., G.S., C.S.S., and Â.L.; writing-original draft, J.M., G.S., C.S.S., and Â.L.; writing-review and editing, J.M., G.S., C.S.S., and Â.L. All authors have read and agreed to the published version of the manuscript.

Funding: This research received no external funding.

Institutional Review Board Statement: Not applicable.

Informed Consent Statement: Informed consent was obtained from all subjects involved in the study.

Data Availability Statement: Not applicable.

Conflicts of Interest: The authors declare no conflict of interest.

\section{References}

1. Schoper, Y.; Gemünden, H.; Nguyen, N. Fifteen future trends for Project Management in 2025. In Future Trends in Project, Programme and Portfolio Management 2016, Proceedings of the International IPMA Expert Seminar, Zurich, Switzerland, 18-19 February 2016; IPMA: Amsterdam, The Netherlands, 2016; pp. 23-43.

2. Sabini, L.; Muzio, D.; Alderman, N. 25 years of 'sustainable projects'. What we know and what the literature says. Int. J. Proj. Manag. 2019, 37, 820-838. [CrossRef]

3. Hwang, B.-G.; Ng, W.J. Project management knowledge and skills for green construction: Overcoming challenges. Int. J. Proj. Manag. 2013, 31, 272-284. [CrossRef]

4. The APM Body of Knowledge, 5th ed.; Association of Project Management: Princes Risborough, UK, 2006.

5. Individual Competence Baseline Version 4; International Project Management Association: Zurich, Switzerland, 2015.

6. Silvius, G.; de Graaf, M. Exploring the project manager's intention to address sustainability in the project board. J. Clean. Prod. 2019, 208, 1226-1240. [CrossRef]

7. Eskerod, P.; Huemann, M. Sustainable development and project stakeholder management: What standards say. Int. J. Manag. Proj. Bus. 2013, 6. [CrossRef]

8. Silvius, G.; Schipper, R. Sustainability in project management: A literature review and impact analysis. Soc. Bus. 2014, 4, 63-96. [CrossRef]

9. Schieg, M. The model of corporate social responsibility in project management. Verslas Teorai Ir Prakika 2009, 4, 315-321. [CrossRef]

10. Silvius, G.; Schipper, R. Exploring variety in factors that stimulate project managers to address sustainability issues. Int. J. Proj. Manag. 2020, 38, 353-367. [CrossRef]

11. Marnewick, C.; Silvius, G.; Schipper, R. Exploring patterns of sustainability stimuli of project managers. Sustainability 2019, 11, 5016. [CrossRef]

12. Marcelino-Sádaba, S.; González-Jaen, L.F.; Pérez-Ezcurdia, A. Using project management as a way to sustainability. From a comprehensive review to a framework definition. J. Clean. Prod. 2015, 99, 1-16. [CrossRef]

13. Martens, M.L.; Carvalho, M.M. Key factors of sustainability in project management context: A survey exploring the project managers' perspective. Int. J. Proj. Manag. 2017, 35, 1084-1102. [CrossRef] 
14. Deland, D. Sustainability through project management and net impact. In Proceedings of the PMI Global Congress North America, Orlando, FL, USA, 10-13 October 2009.

15. Cai, N.; Zhang, S.-j.; Li, L. Sustainable project management: A balance analysis model of effect. In Proceedings of the 2009 International Conference on Management and Service Science, Beijing, China, 20-22 September 2009; pp. 1-4.

16. Elkington, J. Towards the sustainable corporation: Win-win-win business strategies for sustainable development. Calif. Manag. Rev. 1994, 36, 90-100. [CrossRef]

17. Freeman, R.E. Strategic Management: A Stakeholder Approach; Cambridge University Press: Cambridge, UK, 2010.

18. Silvius, G.; Schipper, R. Developing a maturity model for assessing sustainable project management. J. Mod. Proj. Manag. 2015, 3. [CrossRef]

19. Huemann, M.; Silvius, G. Projects to Create the Future: Managing Projects Meets Sustainable Development; Elsevier: Amsterdam, The Netherlands, 2017.

20. Brones, F.; de Carvalho, M.M.; de Senzi Zancul, E. Ecodesign in project management: A missing link for the integration of sustainability in product development? J. Clean. Prod. 2014, 80, 106-118. [CrossRef]

21. Aarseth, W.; Ahola, T.; Aaltonen, K.; Økland, A.; Andersen, B. Project sustainability strategies: A systematic literature review. Int. J. Proj. Manag. 2017, 35, 1071-1083. [CrossRef]

22. Akadiri, P.O. Understanding barriers affecting the selection of sustainable materials in building projects. J. Build. Eng. 2015, 4, 86-93. [CrossRef]

23. Weninger, C.; Huemann, M. Project initiation: Investment analysis for sustainable development. In Banking, Finance, and Accounting: Concepts, Methodologies, Tools, and Applications; IGI Global: Hershey, PA, USA, 2015; pp. 1-17.

24. Silvius, G.; Schipper, R.; Planko, J. Sustainability in Project Management; Gower Publishing, Ltd.: Aldershot, UK, 2012.

25. Silva, C.S.; Magano, J.; Matos, A.; Nogueira, T. Sustainable Quality Management Systems in the Current Paradigm: The Role of Leadership. Sustainability 2021, 13, 2056. [CrossRef]

26. Bell, S.; Morse, S. Measuring Sustainability: Learning from Doing; Routledge: Abingdon, UK, 2013.

27. Edum-Fotwe, F.T.; Price, A.D. A social ontology for appraising sustainability of construction projects and developments. Int. J. Proj. Manag. 2009, 27, 313-322. [CrossRef]

28. Fernández-Sánchez, G.; Rodríguez-López, F. A methodology to identify sustainability indicators in construction project management-Application to infrastructure projects in Spain. Ecol. Indic. 2010, 10, 1193-1201. [CrossRef]

29. Keeble, J.J.; Topiol, S.; Berkeley, S. Using indicators to measure sustainability performance at a corporate and project level. J. Bus. Ethics 2003, 44, 149-158. [CrossRef]

30. Labuschagne, C.; Brent, A.C. An industry perspective of the completeness and relevance of a social assessment framework for project and technology management in the manufacturing sector. J. Clean. Prod. 2008, 16, 253-262. [CrossRef]

31. Silva, C.; Magano, J.; Moskalenko, A.; Nogueira, T.; Dinis, M.A.P.; e Sousa, H.F.P. Sustainable management systems standards (SMSS): Structures, roles, and practices in corporate sustainability. Sustainability 2020. [CrossRef]

32. Silva, C.S.; Pereira, C.; Magano, J. The value of project management to competitiveness: Key factors from a holistic and practical perspective. Int. J. Manag. Proj. Bus. 2021. [CrossRef]

33. Sánchez, M.A. Integrating sustainability issues into project management. J. Clean. Prod. 2015, 96, 319-330. [CrossRef]

34. Molenaar, K.R.; Sobin, N.; Antillón, E.I. A synthesis of best-value procurement practices for sustainable design-build projects in the public sector. J. Green Build. 2010, 5, 148-157. [CrossRef]

35. Silvius, G. Integrating sustainability into project risk management. In Managing Project Risks for Competitive Advantage in Changing Business Environments; Bodea, C.-N., Purnus, A., Huemann, M.H., Hajdu, M., Eds.; IGI Global: Hershey, PA, USA, 2016.

36. Pade, C.; Mallinson, B.; Sewry, D. An elaboration of critical success factors for rural ICT project sustainability in developing countries: Exploring the Dwesa case. J. Inf. Technol. Case Appl. Res. 2008, 10, 32-55. [CrossRef]

37. Labuschagne, C.; Brent, A.C. Sustainable project life cycle management: The need to integrate life cycles in the manufacturing sector. Int. J. Proj. Manag. 2005, 23, 159-168. [CrossRef]

38. Hölzle, K. Designing and implementing a career path for project managers. Int. J. Proj. Manag. 2010, 28, 779-786. [CrossRef]

39. Ika, L.A.; Saint-Macary, J. The project planning myth in international development. Int. J. Manag. Proj. Bus. 2012, 5. [CrossRef]

40. Ahsan, K.; Ho, M.; Khan, S. Recruiting project managers: A comparative analysis of competencies and recruitment signals from job advertisements. Proj. Manag. J. 2013, 44, 36-54. [CrossRef]

41. Turner, J.R. Responsibilities for sustainable development in project and program management. In Survival and sustainability as challenges for projects, Knoepfel, H., Ed.; IPMA—International Project Management Association: Zurich, Switzerland, 2010.

42. Maltzman, R.; Shirley, D. Project manager as a pivot point for implementing sustainability in an enterprise. In Sustainability Integration for Effective Project Management; IGI Global: Hershey, PA, USA, 2013; pp. 261-278.

43. Goedknegt, D. Responsibility for adhering to sustainability in project management. In Proceedings of the 7th Nordic Conference on Construction Economics and Organization, Trondheim, Norway, 12-14 June 2013; pp. 145-154.

44. Project Management Institute. Code of Ethics \& Professional Conduct. Available online: https://www.pmi.org/about/ethics/ code (accessed on 19 February 2021).

45. International Project Management Association. Code of Ethics and Professional Conduct. Available online: https://www.ipma. world/assets/IPMA-Code-of-Ethics-and-Professional-Conduct.pdf (accessed on 19 February 2021).

46. Økland, A. Gap analysis for incorporating sustainability in project management. Proc. Comput. Sci. 2015, 64, 103-109. [CrossRef] 
47. Marôco, J. Análise Estatística com o SPSS Statistics, 7th ed.; ReportNumber Lda: Pêro Pinheiro, Portugal, 2018.

48. Poon, C.; Silvius, G. Factors That Stimulate Project Managers to Consider Sustainability; Exploring the Stimulus Patterns of Canadian Project Managers. J. Menag. Sustain. 2019, 9, 90. [CrossRef]

49. Cordano, M.; Frieze, I.H. Pollution reduction preferences of US environmental managers: Applying Ajzen's theory of planned behavior. Acad. Manag. J. 2000, 43, 627-641.

50. Ruepert, A.; Keizer, K.; Steg, L.; Maricchiolo, F.; Carrus, G.; Dumitru, A.; Mira, R.G.; Stancu, A.; Moza, D. Environmental considerations in the organizational context: A pathway to pro-environmental behaviour at work. Energy Res. Soc. Sci. 2016, 17, 59-70. [CrossRef] 